\title{
Management of a malignant pleural effusion: British Thoracic Society pleural disease guideline 2010
}

\author{
Mark E Roberts, ${ }^{1}$ Edmund Neville, ${ }^{2}$ Richard G Berrisford, ${ }^{3}$ George Antunes, ${ }^{4}$ \\ Nabeel $\mathrm{J} \mathrm{Ali}{ }^{1}$, on behalf of the BTS Pleural Disease Guideline Group
}

${ }^{1}$ Sherwood Forest Hospitals NHS Foundation Trust, UK ${ }^{2}$ Portsmouth Hospitals NHS Trust, UK

${ }^{3}$ Royal Devon and Exeter NHS Trust, UK

${ }^{4}$ South Tees NHS Foundation Trust, UK

\section{Correspondence to} Dr Nabeel J Ali, Sherwood Forest Hospitals NHS Foundation Trust, Kingsmill Hospital, Mansfield Road, Sutton in Ashfield NG17 4JL, UK:

nabeel.ali@sth-tr.nhs.uk

Received 12 February 2010 Accepted 4 March 2010

\section{INTRODUCTION}

The discovery of malignant cells in pleural fluid and/or parietal pleura signifies disseminated or advanced disease and a reduced life expectancy in patients with cancer. ${ }^{1}$ Median survival following diagnosis ranges from 3 to 12 months and is dependent on the stage and type of the underlying malignancy. The shortest survival time is observed in malignant effusions secondary to lung cancer and the longest in ovarian cancer, while malignant effusions due to an unknown primary have an intermediate survival time. ${ }^{2-6}$ Historically, studies showed that median survival times in effusions due to carcinoma of the breast are 5-6 months. However, more recent studies have suggested longer survival times of up to 15 months. ${ }^{7-10} \mathrm{~A}$ comparison of survival times in breast cancer effusions in published studies to 1994 calculated a median survival of 11 months. ${ }^{9}$

Currently, lung cancer is the most common metastatic tumour to the pleura in men and breast cancer in women. ${ }^{4}{ }^{11}$ Together, both malignancies account for $50-65 \%$ of all malignant effusions (table 1). Lymphomas, tumours of the genitourinary tract and gastrointestinal tract account for a further $25 \% .^{2}{ }^{12-14}$ Pleural effusions from an unknown primary are responsible for $7-15 \%$ of all malignant pleural effusions. ${ }^{313} 14 \mathrm{Few}$ studies have estimated the proportion of pleural effusions due to mesothelioma: studies from 1975, 1985 and 1987 identified mesothelioma in 1/271,3/472 and 22/592 patients, respectively, but there are no more recent data to update this in light of the increasing incidence of mesothelioma. ${ }^{4} 1314$

Attempts have been made to predict survival based on the clinical characteristics of pleural fluid. None has shown a definite correlation: a recent systematic review of studies including 433 patients assessing the predictive value of $\mathrm{pH}$ concluded that low $\mathrm{pH}$ does not reliably predict a survival of $<3$ months. ${ }^{15} 16$ In malignant mesothelioma, one study has shown an association between increasing $\mathrm{pH}$ and increasing survival. ${ }^{17}$ Burrows et al showed that only performance status was significantly associated with mortality: median survival was 1.1 months with a Karnofsky score $<30$ and 13.2 months with a score $>70.18$

An algorithm for the management of malignant pleural effusions is shown in figure 1.

\section{CLINICAL PRESENTATION}

- The majority of malignant effusions are symptomatic. (C)

- Massive pleural effusions are most commonly due to malignancy. (C)
The majority of patients who present with a malignant pleural effusion are symptomatic, although up to $25 \%$ are asymptomatic with an incidental finding of effusion on physical examination or by chest radiography. ${ }^{1}$ Dyspnoea is the most common presenting symptom, reflecting reduced compliance of the chest wall, depression of the ipsilateral diaphragm, mediastinal shift and reduction in lung volume. ${ }^{19}$ Chest pain is less common and is usually related to malignant involvement of the parietal pleura, ribs and other intercostal structures. Constitutional symptoms including weight loss, malaise and anorexia generally accompany respiratory symptoms.

A massive pleural effusion is defined as complete or almost complete opacification of a hemithorax on the chest $\mathrm{x}$-ray. It is usually symptomatic and is commonly associated with a malignant cause. ${ }^{20}$ The diagnosis of a malignant pleural effusion is discussed in the guideline on the investigation of a unilateral pleural effusion.

\section{MANAGEMENT OPTIONS}

Treatment options for malignant pleural effusions are determined by several factors: symptoms and performance status of the patient, the primary tumour type and its response to systemic therapy, and degree of lung re-expansion following pleural fluid evacuation. Although small cell lung cancer, lymphoma and breast cancer usually respond to chemotherapy, associated secondary pleural effusions may require intervention during the course of treatment (figure 1). Malignant pleural effusions are often most effectively managed by complete drainage of the effusion and instillation of a sclerosant to promote pleurodesis and prevent recurrence of the effusion. Options for management include observation, therapeutic pleural aspiration, intercostal tube drainage and instillation of sclerosant, thoracoscopy and pleurodesis or placement of an indwelling pleural catheter.

\section{Observation}

- Observation is recommended if the patient is asymptomatic and the tumour type is known. (C)

- Advice should be sought from the respiratory team and/or respiratory multidisciplinary team for symptomatic malignant effusions. $(\boldsymbol{}(\boldsymbol{)})$

The majority of these patients will become symptomatic in due course and require further intervention. There is no evidence that initial thoracentesis carried out according to standard techniques will 
Table 1 Primary tumour site in patients with malignant pleural effusion

\begin{tabular}{lllllll}
\hline $\begin{array}{l}\text { Primary } \\
\text { tumour site }\end{array}$ & $\begin{array}{l}\text { Salyer }^{\mathbf{1 4}} \\
(\mathbf{n = 9 5 )}\end{array}$ & $\begin{array}{l}\text { Chernow }^{\mathbf{1}} \\
(\mathbf{n = 9 6 )}\end{array}$ & $\begin{array}{l}\text { Johnston }^{\mathbf{1 3}} \\
(\mathbf{n = 4 7 2})\end{array}$ & $\begin{array}{l}\text { Sears }^{\mathbf{4}} \\
(\mathbf{n = 5 9 2})\end{array}$ & $\begin{array}{l}\text { Hsu }^{12} \\
(\mathbf{n = 7 8 5})\end{array}$ & Total (\%) \\
\hline Lung & 42 & 32 & 168 & 112 & 410 & $764(37.5)$ \\
Breast & 11 & 20 & 70 & 141 & 101 & $343(16.8)$ \\
Lymphoma & 11 & - & 75 & 92 & 56 & $234(11.5)$ \\
Gastrointestinal & - & 13 & 28 & 32 & 68 & $141(6.9)$ \\
Genitourinary & - & 13 & 57 & 51 & 70 & $191(9.4)$ \\
Other & 14 & 5 & 26 & 88 & 15 & $148(7.8)$ \\
$\begin{array}{l}\text { Unknown } \\
\text { primary }\end{array}$ & 17 & 13 & 48 & 76 & 65 & $219(10.7)$ \\
\hline
\end{tabular}

reduce the chances of subsequent effective pleurodesis after tube drainage. However, repeated thoracentesis may limit the scope for thoracoscopic intervention as it often leads to the formation of adhesions between the parietal and visceral pleura.

\section{Therapeutic pleural aspiration}

- Pleural effusions treated by aspiration alone are associated with a high rate of recurrence of effusion at 1 month so aspiration is not recommended if life expectancy is $>1$ month. (A)

- Caution should be taken if removing $>1.51$ on a single occasion. (C)

Repeated therapeutic pleural aspiration provides transient relief of symptoms and avoids hospitalisation for patients with limited survival expectancy and poor performance status. It is appropriate for frail or terminally ill patients. However, as smallbore chest tubes are widely available, effective and may be

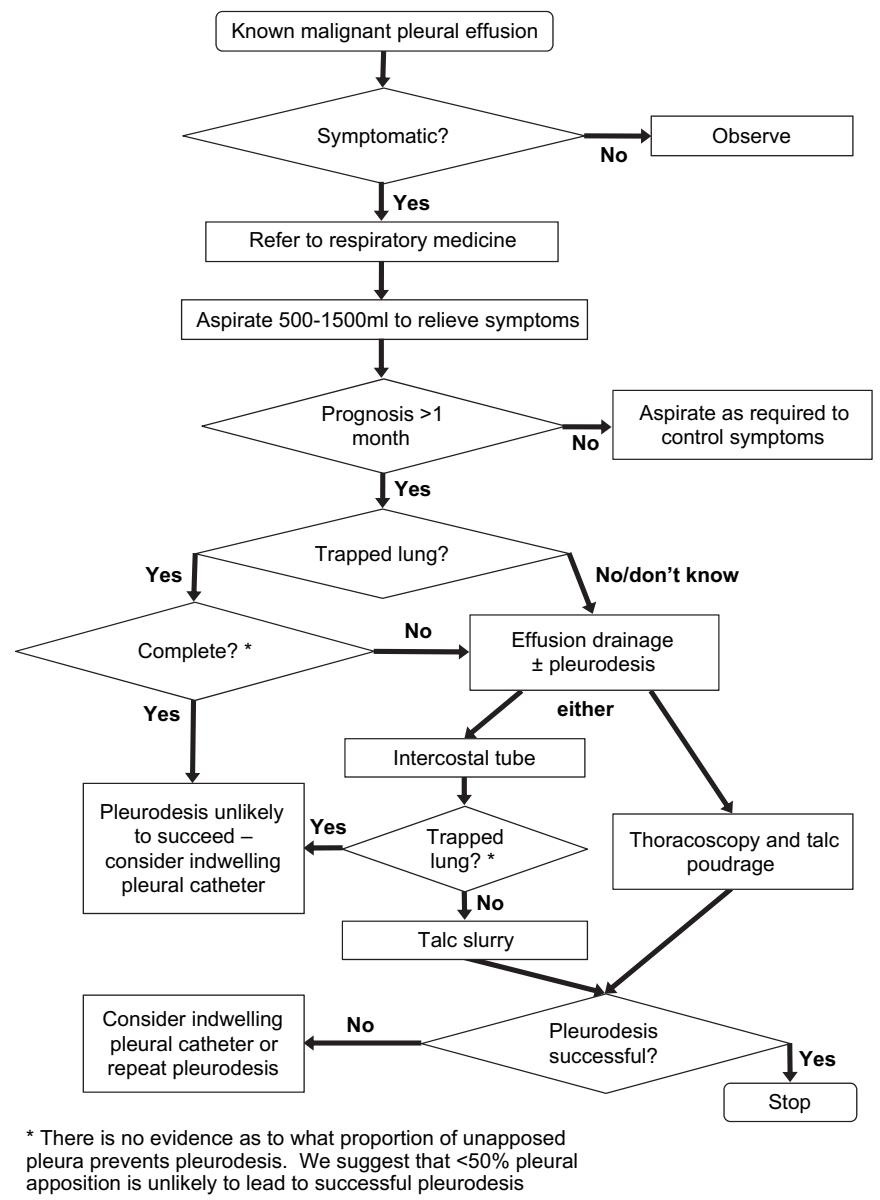

Figure 1 Management algorithm for malignant pleural effusion. inserted with minimal discomfort, ${ }^{21-26}$ they may be preferable. The amount of fluid evacuated by pleural aspiration will be guided by patient symptoms (cough, chest discomfort) ${ }^{27}$ and should be limited to 1.51 on a single occasion. Pleural aspiration alone and intercostal tube drainage without instillation of a sclerosant are associated with a high recurrence rate and a small risk of iatrogenic pneumothorax and empyema. ${ }^{28-36}$ Therapeutic pleural aspiration should take place under ultrasound guidance (see guideline on pleural procedures).

\section{Intercostal tube drainage and intrapleural instillation of sclerosant}

- Other than in patients with a very short life expectancy, small-bore chest tubes followed by pleurodesis are preferable to recurrent aspiration. $(\boldsymbol{V})$

- Intercostal drainage should be followed by pleurodesis to prevent recurrence unless lung is significantly trapped. (A)

Pleurodesis is thought to occur through a diffuse inflammatory reaction and local activation of the coagulation system with fibrin deposition. ${ }^{37} 38$ Increased pleural fibrinolytic activity is associated with failure of pleurodesis, as is extensive tumour involvement of the pleura. ${ }^{39} 40$ Intercostal drainage without pleurodesis is associated with a high rate of effusion recurrence and should be avoided (see evidence table available on the BTS website at www. brit-thoracic.org.uk). A suggested method for undertaking pleurodesis is shown in box 1 .

In animals the effectiveness of pleurodesis may be reduced by concomitant use of corticosteroids. Recent evidence in rabbits has shown reduced pleural inflammatory reaction and, in some cases, prevention of pleurodesis with administration of corticosteroids at the time of talc pleurodesis. ${ }^{41}$ A subgroup analysis comparing the efficacy of pleurodesis in the presence and absence of non-randomised oral corticosteroid use also suggested a negative effect of corticosteroids on efficacy. ${ }^{42}$ The administration of non-steroidal anti-inflammatory drugs (NSAIDs) at the time of pleurodesis is more contentious. Animal studies have suggested that the use of NSAIDs may impair the action of pleurodesis agents, but there is no evidence from human studies. $^{43}$

\section{Size of intercostal tube}

- Small-bore (10-14 F) intercostal catheters should be the initial choice for effusion drainage and pleurodesis. (A) Conventional large-bore intercostal tubes (24-32 F) have been employed in most studies involving sclerosing agents. ${ }^{44}$ They have traditionally been used because they are thought to be less

\section{Box 1 How to perform talc slurry chemical pleurodesis}

- Insert small-bore intercostal tube (10-14 F).

- Controlled evacuation of pleural fluid.

- Confirm full lung re-expansion and position of intercostal tube with chest $\mathrm{x}$-ray. In cases where incomplete expansion occurs, see text regarding trapped lung.

- Administer premedication prior to pleurodesis (see text).

- Instill lidocaine solution ( $3 \mathrm{mg} / \mathrm{kg}$; maximum $250 \mathrm{mg}$ ) into pleural space followed by $4-5 \mathrm{~g}$ sterile graded talc in $50 \mathrm{ml}$ $0.9 \%$ saline.

- Clamp tube for 1-2 h

- Remove intercostal tube within 24-48 h. 
prone to obstruction by fibrin plugs, but there is little published evidence to confirm this. The placement of large-bore tubes is perceived to be associated with significant discomfort ${ }^{45}$ and this has led to the assessment of smaller bore tubes $(10-14 \mathrm{~F})$ for drainage and administration of sclerosing agents. ${ }^{22} 4647$ Three randomised trials investigating the difference in efficacy between small- and large-bore chest tubes all concluded that they were equivalent (see evidence table available on the BTS website at www.brit-thoracic.org.uk). ${ }^{21-23}$ Studies using smallbore intercostal tubes with commonly used sclerosants have reported similar success rates to large-bore tubes and appear to cause less discomfort. ${ }^{24-26} 48$ The small-bore tubes in these studies were inserted either at the patient's bedside by a physician or under radiological guidance.

Small-bore tubes have been used for ambulatory or outpatient pleurodesis. Patz and colleagues used a fluoroscopically-placed tube (10 F) connected to a closed gravity drainage bag system for this purpose. ${ }^{49}$ Bleomycin was the preferred sclerosing agent and the pleurodesis success rate approached 80\%. Ambulatory drainage is discussed further in the section on indwelling pleural catheters.

\section{Fluid drainage, pleurodesis and trapped lung}

- Large pleural effusions should be drained in a controlled fashion to reduce the risk of re-expansion pulmonary oedema. (C)

- In patients where only partial pleural apposition can be achieved, chemical pleurodesis may still be attempted and may provide symptomatic relief. (B)

- In symptomatic cases where pleural apposition cannot be achieved ('trapped lung'), indwelling pleural catheters offer a more attractive therapeutic approach than recurrent aspiration. ( $\downarrow$ )

- Once effusion drainage and lung re-expansion have been radiographically confirmed, pleurodesis should not be delayed. (B)

- Suction to aid pleural drainage before and after pleurodesis is usually unnecessary but, if applied, a high-volume low-pressure system is recommended. (C)

Large pleural effusions should be drained incrementally, draining a maximum of 1.51 on the first occasion. Any remaining fluid should be drained $1.5 \mathrm{l}$ at a time at $2 \mathrm{~h}$ intervals, stopping if the patient develops chest discomfort, persistent cough or vasovagal symptoms. Re-expansion pulmonary oedema is a well-described serious but rare complication following rapid expansion of a collapsed lung through evacuation of large amounts of pleural fluid on a single occasion and the use of early and excessive pleural suction. ${ }^{50}$ Putative pathophysiological mechanisms include reperfusion injury of the underlying hypoxic lung, increased capillary permeability and local production of neutrophil chemotactic factors such as interleukin-8. ${ }^{52} 53$

The most important requirement for successful pleurodesis is satisfactory apposition of the parietal and visceral pleura, confirmed radiologically. ${ }^{44} 5455$ Incomplete lung re-expansion may be due to a thick visceral peel ('trapped lung'), pleural loculations, proximal large airway obstruction or a persistent air leak. Most studies indicate that the lack of a response following instillation of a sclerosant is associated with incomplete lung expansion. ${ }^{56}$ Where complete lung re-expansion or pleural apposition is not achieved, pleurodesis may still be attempted or an indwelling pleural catheter may be inserted. Robinson and colleagues reported a favourable response in 9 out of 10 patients with partial re-expansion of the lung in a study using doxy- cycline as a sclerosing agent. ${ }^{57}$ The amount of trapped lung compatible with successful pleurodesis is unknown. Complete lack of pleural apposition will prevent pleurodesis: consideration of an indwelling pleural catheter is recommended in this situation. Where more than half the visceral pleura and parietal pleura are apposed, pleurodesis may be attempted although there are no studies to support this recommendation.

The amount of pleural fluid drained per day before the instillation of a sclerosant $(<150 \mathrm{ml} /$ day) is less relevant for successful pleurodesis than radiographic confirmation of fluid evacuation and lung re-expansion. In a randomised study, a shorter period of intercostal tube drainage and hospital stay was seen in the group in whom sclerotherapy was undertaken as soon as complete lung re-expansion was documented (majority $<24 \mathrm{~h}$ ) than in the group in whom pleurodesis was attempted only when the fluid drainage was $<150 \mathrm{ml} /$ day. The success rate in both groups approached $80 \%{ }^{55}$ After sclerosant instillation, the duration of intercostal drainage appears not to affect the chances of successful pleurodesis, although the only randomised study to address this question was underpowered. ${ }^{58}$

Suction may rarely be required for incomplete lung expansion and a persistent air leak. When suction is applied, the use of high-volume low-pressure systems is recommended with a gradual increment in pressure to about $-20 \mathrm{~cm} \mathrm{H}_{2} \mathrm{O}$.

\section{Analgesia and premedication}

- Lidocaine (3 mg/kg; maximum $250 \mathrm{mg}$ ) should be administered intrapleurally just prior to sclerosant administration. (B)

- Premedication should be considered to alleviate anxiety and pain associated with pleurodesis. (C)

Intrapleural administration of sclerosing agents may be painful; significant pain is reported in $7 \%$ patients receiving talc to $60 \%$ with historical agents such as doxycycline. ${ }^{57}$ Discomfort can be reduced by administering local anaesthetic via the drain prior to pleurodesis. Lidocaine is the most frequently studied local anaesthetic for intrapleural administration. The onset of action of lidocaine is almost immediate and it should therefore be administered just before the sclerosant. The maximum dose of lidocaine is $3 \mathrm{mg} / \mathrm{kg}$ (21 $\mathrm{ml}$ of a $1 \%$ lidocaine solution for a $70 \mathrm{~kg}$ male), with a ceiling of $250 \mathrm{mg}$. The issue of safety has been highlighted in two studies. Wooten et $a l^{60}$ showed that the mean peak serum concentration of lidocaine following $150 \mathrm{mg}$ of intrapleural lidocaine was $1.3 \mu \mathrm{g} / \mathrm{ml}$, well below the serum concentration associated with central nervous system side effects (ie, $>3 \mu \mathrm{g} / \mathrm{ml}$ ). In an earlier study of 20 patients, larger doses of lidocaine were necessary to achieve acceptable levels of local anaesthesia. The patients receiving $250 \mathrm{mg}$ lidocaine had more frequent pain-free episodes than those given $200 \mathrm{mg}$, while serum levels remained within the therapeutic range. Side effects were limited to transient paraesthesiae in a single patient. ${ }^{61}$ The reason for the significant difference in analgesia between the two groups with only a small increment in the lidocaine dose was unclear.

There are no studies to inform a recommendation on the use of premedication and sedation in non-thoracoscopic pleurodesis. Pleurodesis is an uncomfortable procedure and is associated with anxiety for the patient. The use of sedation may be helpful to allay such fears and induce amnesia. The level of sedation should be appropriate to relieve anxiety but sufficient to maintain patient interaction. Sedation employed before pleurodesis should be conducted with continuous monitoring with pulse oximetry and in a setting where resuscitation equipment is available. ${ }^{62}$ Further research is underway to address this issue. 
Sclerosant and complications

- Talc is the most effective sclerosant available for pleurodesis. (A)

- Graded talc should always be used in preference to ungraded talc as it reduces the risk of arterial hypoxaemia complicating talc pleurodesis. (B)

- Talc pleurodesis is equally effective when administered as a slurry or by insufflation. (B)

- Bleomycin is an alternative sclerosant with a modest efficacy rate. (B)

- Pleuritic chest pain and fever are the most common side effects of sclerosant administration. (B)

An ideal sclerosing agent must possess several essential qualities: a high molecular weight and chemical polarity, low regional clearance, rapid systemic clearance, a steep dose-response curve and be well tolerated with minimal or no side effects. The choice of a sclerosing agent will be determined by the efficacy or success rate of the agent, accessibility, safety, ease of administration, number of administrations to achieve a complete response and cost. Despite the evaluation of a wide variety of agents, to date no ideal sclerosing agent exists.

Comparison of sclerosing agents is hampered by the lack of comparative randomised trials, different eligibility criteria and disparate criteria for measuring response and end points. A complete response is usually defined as no reaccumulation of pleural fluid after pleurodesis until death, and a partial response as partial reaccumulation of fluid radiographically but not requiring further pleural intervention such as aspiration. However, some studies use a 30-day cut-off. A recent Cochrane review concluded that thoracoscopic talc pleurodesis is probably the optimal method for pleurodesis. ${ }^{63}$ This view is supported by a systematic review. ${ }^{64}$ Studies are presently underway investigating other agents including the profibrotic cytokine transforming growth factor $\beta$.

\section{Tetracycline}

Until recently, tetracycline had been the most popular and widely used sclerosing agent in the UK. Unfortunately, parenteral tetracycline is no longer available for this indication in many countries as its production has ceased. ${ }^{65}$

\section{Sterile talc}

Talc $\left(\mathrm{Mg}_{3} \mathrm{Si}_{4} \mathrm{O}_{10}(\mathrm{OH})_{2}\right)$ is a trilayered magnesium silicate sheet that is inert and was first used as a sclerosing agent in $1935{ }^{66}$ Talc used for intrapleural administration is asbestos-free and sterilised effectively by dry heat exposure, ethylene oxide and gamma radiation. It may be administered in two ways: at thoracoscopy using an atomiser termed 'talc poudrage' or via an intercostal tube in the form of a suspension termed 'talc slurry'.

Success rates (complete and partial response) for talc slurry range from $81 \%$ to $100 \%$. ${ }^{30} 545667-70$ The majority of studies have used talc slurry alone and only a limited number of comparative studies have been published (see evidence table available on the BTS website at www.brit-thoracic.org.uk). A truncated randomised study by Lynch and colleagues ${ }^{71}$ compared talc slurry (5 g) with bleomycin (60000 units) and tetracycline $(750 \mathrm{mg})$. Although the study was terminated early because of the removal of tetracycline from the US market, analysis of the data to that point revealed no differences between the three treatment groups 1 month after pleurodesis. In a randomised trial between talc slurry (5 g) and bleomycin (60000 units), $90 \%$ of the talc group achieved a complete response at 2 weeks compared with $79 \%$ of the bleomycin group, which was statistically insignificant. ${ }^{72}$ Three studies have directly compared talc slurry with talc poudrage (see evidence table available on the BTS website at www.brit-thoracic.org. uk). ${ }^{73-75}$ For one randomised study the data are available only in abstract form. ${ }^{73}$ It suggests superiority of poudrage over slurry, but limited data are available to validate this conclusion. Of the other two studies, Stefani et al compared medical thoracoscopy and talc poudrage with talc slurry in a non-randomised way. ${ }^{75}$ Their results suggest superiority of poudrage over slurry, but the two groups were not equal with respect to performance status. In the largest study, Dresler et al compared a surgical approach to talc poudrage with talc slurry. ${ }^{74}$ They concluded equivalence, but $44 \%$ of patients dropped out of the study before the 30 -day end point due to deaths and a requirement of $90 \%$ lung reexpansion radiologically after intervention to be included in the analysis.

Three studies have compared talc poudrage with other agents administered via an intercostal tube. One compared bleomycin (see below) and the other two tetracyclines (see evidence table available on the BTS website at www.brit-thoracic.org.uk). ${ }^{76-78}$ Diacon et al concluded that talc insufflation at medical thoracoscopy was superior to bleomycin instillation on efficacy and cost grounds. ${ }^{76}$ Kuzdzal et al and Fentiman et al both showed an advantage of talc insufflation over tetracyclines. ${ }^{77} 78$ Each of the three studies analysed fewer than 40 patients.

Talc slurry is usually well tolerated and pleuritic chest pain and mild fever are the most common side effects observed. A serious complication associated with the use of talc is adult respiratory distress syndrome or acute pneumonitis leading to acute respiratory failure. There have been many reports of pneumonitis associated with talc pleurodesis, although predominantly from the UK and the USA where historically non-graded talc has been used. ${ }^{56} 79-87$ The mechanism of acute talc pneumonitis is unclear and has been reported with both talc poudrage and slurry. ${ }^{56} 80$ This complication is related to the grade of talc used. Maskell and colleagues undertook two studies to determine this association. In the first study they randomised 20 patients to pleurodesis using either mixed talc or tetracycline and compared DTPA clearance in the contralateral lung with that undergoing pleurodesis at $48 \mathrm{~h}$ after pleurodesis. ${ }^{88} \mathrm{DTPA}$ clearance half time decreased by more in the talc group, which is a marker of increased lung inflammation. There was also a greater arterial desaturation in those patients exposed to talc. In the second part of the study, graded (particle size $>15 \mu \mathrm{m}$ ) and non-graded $(50 \%$ particle size $<15 \mu \mathrm{m})$ talc were compared. There was a greater alveolar-arterial oxygen gradient in the group exposed to non-graded talc at $48 \mathrm{~h}$ after pleurodesis. In a subsequent cohort study of 558 patients who underwent thoracoscopic pleurodesis using graded talc, there were no episodes of pneumonitis. ${ }^{89}$

Two studies have investigated the systemic distribution of talc particles in rats after talc pleurodesis. The earlier study using uncalibrated talc found widespread organ deposition of talc particles in the lungs, heart, brain, spleen and kidneys at $48 \mathrm{~h}$. The later study used calibrated talc and found liver and spleen deposition (but no lung deposition) at $72 \mathrm{~h}$, but no evidence of pleurodesis in the treated lungs. ${ }^{90} 91$ A further study in rabbits found greater systemic distribution of talc with 'normal' (small particle talc). ${ }^{92}$ This supports the evidence from clinical studies that large particle talc is preferable to small particle talc.

\section{Bleomycin}

Bleomycin is the most widely used antineoplastic agent for the management of malignant pleural effusions. Its mechanism of action is predominantly as a chemical sclerosant similar to talc 
and tetracycline. Although $45 \%$ of the administered bleomycin is absorbed systemically, it has been shown to cause minimal or no myelosuppression. ${ }^{93}$ Bleomycin is an effective sclerosant with success rates after a single administration ranging from $58 \%$ to $85 \%$ with a mean of $61 \%$. No studies have demonstrated superiority over talc. ${ }^{42} 717294-102$ It has an acceptable side effect profile with fever, chest pain and cough the most common adverse effects. ${ }^{99} 102$ The recommended dose is 60000 units mixed in normal saline. Bleomycin has also been used in studies evaluating small-bore intercostal tubes placed under radiological guidance with similar efficacy rates. ${ }^{46} 4849103$ In the USA, bleomycin is a more expensive sclerosant than talc, but this is not the case in Europe where non-proprietary formulations are available. $^{42} 72104$

\section{Rotation following pleurodesis}

- Patient rotation is not necessary after intrapleural instillation of sclerosant. (A)

Rotation of the patient to achieve adequate distribution of the agent over the pleura has been described in many studies. However, rotating the patient is time consuming, inconvenient and uncomfortable. A study using radiolabelled tetracycline showed that tetracycline is dispersed throughout the pleural space within seconds and rotation of the patient did not influence distribution. ${ }^{105}$ A subsequent randomised trial using tetracycline, minocycline and doxycycline revealed no significant difference in the success rate of the procedure or duration of fluid drainage between the rotation and non-rotation groups. ${ }^{106} \mathrm{~A}$ similar study using talc showed no difference in distribution of talc after $1 \mathrm{~min}$ or $1 \mathrm{~h}$ and no difference in the success rate of pleurodesis at 1 month. ${ }^{107}$

\section{Clamping and removal of intercostal tube}

- The intercostal tube should be clamped for $1 \mathrm{~h}$ after sclerosant administration. (C)

- In the absence of excessive fluid drainage (>250 ml/ day) the intercostal tube should be removed within $24-48 \mathrm{~h}$ of sclerosant administration. (C)

Clamping of the intercostal tube following intrapleural administration of the sclerosant should be brief $(1 \mathrm{~h})$ to prevent the sclerosant from immediately draining back out of the pleural space, although there are no studies to prove that this is necessary. ${ }^{105}$ Intercostal tube removal has been recommended when fluid drainage is $<150 \mathrm{ml} /$ day, but there is little evidence to support this action. ${ }^{58} 68108109$ In the only randomised study that has addressed the issue, Goodman and Davies randomised patients to $24 \mathrm{~h}$ versus $72 \mathrm{~h}$ drainage following talc slurry pleurodesis regardless of volume of fluid drainage. They found no difference in pleurodesis success, although they did not reach the recruitment target based upon the power calculation. In the absence of any evidence that protracted drainage is beneficial, and given the discomfort associated with prolonged drainage, we recommend removal of the intercostal tube within $24-48 \mathrm{~h}$ after the instillation of the sclerosant, provided the lung remains fully re-expanded and there is satisfactory evacuation of pleural fluid on the chest $\mathrm{x}$-ray.

\section{Pleurodesis failure}

The most likely cause of pleurodesis failure is the presence of trapped lung. There is no reliable way to predict pleurodesis failure: a recent systematic review found that an arbitrary cutoff of $\mathrm{pH}<7.20$ did not predict pleurodesis failure. ${ }^{15}$ Where pleurodesis fails, there is no evidence available as to the most effective secondary procedure. We recommend that further evacuation of pleural fluid should be attempted with either a repeat pleurodesis or insertion of indwelling pleural catheter, depending upon the presence of trapped lung. Surgical pleurectomy has been described as an alternative option for patients with mesothelioma (see later).

\section{Malignant seeding at intercostal tube or port site}

- Patients with proven or suspected mesothelioma should receive prophylactic radiotherapy to the site of thoracoscopy, surgery or large-bore chest drain insertion, but there is little evidence to support this for pleural aspirations or pleural biopsy. (B)

Local tumour recurrence or seeding following diagnostic and therapeutic pleural aspiration, pleural biopsy, intercostal tube insertion and thoracoscopy is uncommon in non-mesothelioma malignant effusions. ${ }^{110-113}$ However, in mesothelioma up to $40 \%$ of patients may develop malignant seeding at the site of pleural procedures. Three randomised studies have addressed the efficacy of procedure site radiotherapy to prevent tract metastasis (see evidence table available on the BTS website at www. brit-thoracic.org.uk). ${ }^{114-116}$ Boutin and colleagues ${ }^{114}$ found that local metastases were prevented in patients who received radiotherapy (21 Gy in three fractions) to the site of thoracoscopy. All the patients received radiotherapy within 2 weeks of thoracoscopy. The incidence of tract metastases in the control group in this study was $40 \%$. This study was followed by a longitudinal study that supported its conclusions. ${ }^{117}$ In two later studies including sites from a wider range of procedures such as needle biopsy and chest drain, the incidence of tract metastases was not significantly different. Bydder and colleagues showed no benefit of a single 10 Gy radiotherapy fraction to the intervention site in preventing recurrence. ${ }^{116}$ All the patients received radiotherapy within 15 days of the procedure, but $46 \%$ of procedures were fine needle aspirations. O'Rourke and colleagues used the same radiotherapy dose as Boutin but to smaller fields. They found no benefit of radiotherapy, but again included a range of procedures including needle biopsy. The study included 60 patients but only 16 thoracoscopies, 7 in the radiotherapy group and 9 in the best supportive care group. Tract metastases occurred in 4 patients in the best supportive care group (a rate of 44\%) and none in the radiotherapy group. ${ }^{115}$ This is very similar to the incidence of tract metastasis in the study by Boutin et al (40\%). The other procedures were pleural biopsies (45\%) and chest tubes (25\%). A longitudinal study by Agarwal et al found the highest rate of pleural tract metastases in association with thoracoscopy (16\%), thoracotomy $(24 \%)$ and chest tube $(9 \%)$, but a much lower rate in association with pleural aspiration (3.6\%) and image-guided biopsy $(4.5 \%) .{ }^{118}$ Careful analysis of the available data therefore supports the use of radiotherapy to reduce tract metastasis after significant pleural instrumentation (thoracoscopy, surgery or large-bore chest drain), but not for less invasive procedures such as pleural biopsy or pleural aspiration. A larger study to specifically address this question would be of use.

A cohort of 38 patients described by West et al reported an incidence of pleural tract metastasis after radiotherapy of $5 \%$, but in these cases the metastasis occurred at the edge of the radiotherapy field. Of six patients who received radiotherapy after an indwelling pleural catheter, one subsequently developed pleural tract metastasis. ${ }^{119}$ There are, at present, insufficient data on which to make a recommendation about the use of radiotherapy in the presence of indwelling pleural catheters.

The role of prophylactic radiotherapy following pleural procedures in non-mesothelioma malignant effusions has not been established and therefore cannot be recommended. 
Intrapleural fibrinolytics

- Intrapleural instillation of fibrinolytic drugs is recommended for the relief of distressing dyspnoea due to multiloculated malignant effusion resistant to simple drainage. (C)

The use of fibrinolytic agents to ameliorate symptoms related to complex pleural effusions has been described in several studies although there are no randomised controlled trials.

Davies et al found that intrapleural streptokinase increased pleural fluid drainage and led to radiographic improvement and amelioration of symptoms in 10 patients with multiloculated or septated malignant effusions. Intrapleural streptokinase was well tolerated and no allergic or haemorrhagic complications were reported. ${ }^{120}$ Gilkeson et al ${ }^{121}$ preferred urokinase in their prospective but non-randomised study. Twenty-two malignant pleural effusions were treated with urokinase resulting in a substantial increase in pleural fluid output in patients both with and without radiographic evidence of loculations. The majority then underwent pleurodesis with doxycycline resulting in a complete response rate of $56 \%$. Similarly, no allergic or haemorrhagic complications were encountered. In the largest series, 48 patients unfit for surgical release of trapped lung after incomplete lung re-expansion following tube drainage were given intrapleural urokinase. ${ }^{122}$ Breathlessness was improved in 29 patients, 27 of whom eventually successfully achieved pleurodesis. This study compared cases with historical controls treated solely with saline flushes and in whom breathlessness was not assessed.

None of these studies is large enough to accurately describe the safety profile of fibrinolytic drugs in this setting. Immunemediated or haemorrhagic complications have rarely been described with the administration of intrapleural fibrinolytics in contrast to systemic administration of these agents. ${ }^{123} 124 \mathrm{~A}$ chest physician should be involved in the care of all patients receiving this treatment.

\section{Thoracoscopy}

- In patients with good performance status, thoracoscopy is recommended for diagnosis of suspected malignant pleural effusion and for drainage and pleurodesis of a known malignant pleural effusion. (B)

- Thoracoscopic talc poudrage should be considered for the control of recurrent malignant pleural effusion. (B)

- Thoracoscopy is a safe procedure with low complication rates. (B)

Thoracoscopy (under sedation or general anaesthesia) has grown in popularity as a diagnostic and therapeutic tool for malignant effusions. Under sedation, it is now widely used by respiratory physicians in the diagnosis and management of pleural effusions in patients with good performance status. ${ }^{125-128}$ Patient selection for thoracoscopy and talc poudrage is important in view of the invasive nature of the procedure and cost. ${ }^{129}$ A significant benefit of thoracoscopy is the ability to obtain a diagnosis, drain the effusion and perform a pleurodesis during the same procedure.

The diagnostic yield and accuracy of thoracoscopy for malignant effusions is $>90 \%{ }^{99} 125127 \quad 130131$ Talc poudrage performed during thoracoscopy is an effective method for controlling malignant effusions with a pleurodesis success rate of $77-100 \%$. $^{6} 6897132-138$ Randomised studies have established the superiority of talc poudrage over both bleomycin and tetracyclines (see evidence table available on the BTS website at www.brit-thoracic.org.uk). ${ }^{73}{ }^{76-78}$ One large randomised study comparing talc poudrage with talc slurry failed to establish a difference in efficacy between the two techniques. ${ }^{74}$ A further small non-randomised study comparing these two techniques also established equivalence. ${ }^{133}$ A large study has established the safety of talc poudrage using large particle talc; no cases of respiratory failure were seen in this cohort of 558 patients. ${ }^{89}$ Talc poudrage is known particularly to be effective in the presence of effusions due to carcinoma of the breast. ${ }^{139}$

Thoracoscopy has less to offer in patients with a known malignant pleural effusion and a clearly trapped lung on the chest x-ray. However, under general anaesthesia, reinflation of the lung under thoracoscopic vision will inform whether the lung is indeed trapped and therefore guide the decision to perform talc poudrage or insert a pleural catheter. The procedure can facilitate breaking up of loculations or blood clot in haemorrhagic malignant pleural effusion and can allow the release of adhesions and thereby aid lung re-expansion and apposition of the pleura for talc poudrage. ${ }^{140} 141$

Thoracoscopy is a safe and well-tolerated procedure with a low perioperative mortality rate $(<0.5 \%) .{ }^{6} 126129142$ The most common major complications are empyema and acute respiratory failure secondary to infection or re-expansion pulmonary oedema, although the latter may be avoided by staged evacuation of pleural fluid and allowing air to replace the fluid. ${ }^{127} 129143$

\section{Long-term ambulatory indwelling pleural catheter drainage}

- Ambulatory indwelling pleural catheters are effective in controlling recurrent and symptomatic malignant effusions in selected patents. (B)

Insertion of a tunnelled pleural catheter is an alternative method for controlling recurrent and symptomatic malignant effusions including patients with trapped lung. Several catheters have been developed for this purpose and the published studies employing them have reported encouraging results. ${ }^{140} 144-147$ The presence of foreign material (silastic catheter) within the pleural space stimulates an inflammatory reaction, and vacuum drainage bottles connected to the catheter every few days encourage re-expansion and obliteration of the pleural space. Most catheters can be removed after a relatively short period.

In the only randomised and controlled study to date, Putnam and colleagues ${ }^{145}$ compared a long-term indwelling pleural catheter with doxycycline pleurodesis via a standard intercostal tube. The length of hospitalisation for the indwelling catheter group was significantly shorter (1 day) than that of the doxycycline pleurodesis group (6 days). Spontaneous pleurodesis was achieved in 42 of the 91 patients in the indwelling catheter group. A late failure rate (defined as reaccumulation of pleural fluid after initial successful control) of $13 \%$ was reported compared with $21 \%$ for the doxycycline pleurodesis group. There was a modest improvement in the quality of life and dyspnoea scores in both groups. The complication rate was higher $(14 \%)$ in the indwelling catheter group and included local cellulitis (most common) and, rarely, tumour seeding of the catheter tract.

The largest series to date reported on 250 patients, with at least partial symptom control achieved in $88.8 \%$. Spontaneous pleurodesis occurred in $42.9 \%$ while catheters remained until death in $45.8 \%{ }^{148}$ A more recent series of 231 patients treated with an indwelling catheter to drain pleural effusion reported a removal rate of $58 \%$ after spontaneous cessation of drainage, with only $3.8 \%$ reaccumulation and $2.2 \%$ infection. ${ }^{147}$ This group included those with trapped lung (12.5\% of all patients) or who had failed other therapy. A further series of 48 patients reported a spontaneous pleurodesis rate of $48 \% .{ }^{149}$ Pien et al studied a group of 11 patients in whom an indwelling catheter 
was placed specifically for a malignant effusion in the presence of trapped lung; 10 patients reported symptomatic improvement. ${ }^{144}$

A recent series of 45 patients reported by Janes et al described three cases of catheter tract metastasis associated with indwelling pleural catheters occurring between 3 weeks and 9 months after insertion. Metastases occurred in 2 of 15 patients with mesothelioma but in only 1 of 30 patients with other metastatic malignancy. ${ }^{150}$

An indwelling pleural catheter is therefore an effective option for controlling recurrent malignant effusions when length of hospitalisation is to be kept to a minimum (reduced life expectancy) or where patients are known or are suspected to have trapped lung and where expertise and facilities exist for outpatient management of these catheters. Although there is a significant cost associated with the disposable vacuum drainage bottles that connect to indwelling pleural catheters, there may be a cost reduction associated with reduced length of hospital stay or avoidance of hospital admission.

\section{Pleurectomy}

Pleurectomy has been described as a treatment for malignant pleural effusions. Open pleurectomy is an invasive procedure with significant morbidity. Complications may include empyema, haemorrhage and cardiorespiratory failure (operative mortality rates of $10-19 \%$ have been described). ${ }^{151-153}$ Pleurectomy performed by video-assisted thoracic surgery has been described in a small series of patients with mesothelioma. There is not sufficient evidence to recommend this as an alternative to pleurodesis or indwelling pleural catheter in recurrent effusions or trapped lung. ${ }^{154}$

Competing interests No member of the Guideline Group is aware of any competing interests.

Provenance and peer review The draft guideline was available for online public consultation (July/August 2009) and presented to the BTS Winter Meeting (December 2009). Feedback was invited from a range of stakeholder institutions (see Introduction). The draft guideline was reviewed by the BTS Standards of Care Committee (September 2009)

\section{REFERENCES}

1. Chernow B, Sahn SA. Carcinomatous involvement of the pleura: an analysis of 96 patients. Am J Med 1977:63:695-702. (3).

2. Abbruzzese JL, Abbruzzese MC, Hess KR, et al. Unknown primary carcinoma: natural history and prognostic factors in 657 consecutive patients. J Clin Oncol 1994:12:1272-80. $(2+)$.

3. van de Molengraft FJ, Vooijs GP. Survival of patients with malignancy-associated effusions. Acta Cytol 1989;33:911-16. (2+).

4. Sears D, Hajdu SI. The cytologic diagnosis of malignant neoplasms in pleural and peritoneal effusions. Acta Cytol 1987;31:85-97. (2+).

5. Bonnefoi H, Smith IE. How should cancer presenting as a malignant pleural effusion be managed? Br J Cancer 1996;74:832-5. (2-).

6. Kolschmann S, Ballin A, Gillissen A. Clinical efficacy and safety of thoracoscopic talc pleurodesis in malignant pleural effusions. Chest 2005; 128:1431-5. (2-).

7. Raju RN, Kardinal CG. Pleural effusion in breast carcinoma: analysis of 122 cases. Cancer 1981;48:2524-7. (3).

8. Fentiman IS, Millis R, Sexton S, et al. Pleural effusion in breast cancer: a review of 105 cases. Cancer 1981:47:2087-92. (3)

9. Banerjee AK, Willetts I, Robertson JF, et al. Pleural effusion in breast cancer: a review of the Nottingham experience. Eur J Surg Oncol 1994;20:33-6. (3)

10. Dieterich M, Goodman SN, Rojas-Corona RR, et al. Multivariate analysis of prognostic features in malignant pleural effusions from breast cancer patients. Acta Cytol 1994;38:945-52. (3)

11. DiBonito L, Falconieri G, Colautti I, et al. The positive pleural effusion. A retrospective study of cytopathologic diagnoses with autopsy confirmation. Acta Cytol 1992;36:329-32. $(2+)$.

12. Hsu C. Cytologic detection of malignancy in pleural effusion: a review of 5,255 samples from 3,811 patients. Diagn Cytopathol 1987;3:8-12. (2-).

13. Johnston WW. The malignant pleural effusion. A review of cytopathologic diagnoses of 584 specimens from 472 consecutive patients. Cancer 1985;56:905-9. (3).
14. Salyer WR, Eggleston JC, Erozan YS. Efficacy of pleural needle biopsy and pleural fluid cytopathology in the diagnosis of malignant neoplasm involving the pleura. Chest 1975;67:536-9. (3)

15. Heffner JE, Heffner JN, Brown LK. Multilevel and continuous pleural fluid pH likelihood ratios for evaluating malignant pleural effusions. Chest

2003;123:1887-94. (1-)

16. Rodriguez-Panadero F, Lopez Mejias J. Low glucose and pH levels in malignant pleural effusions. Diagnostic significance and prognostic value in respect to pleurodesis. Am Rev Respir Dis 1989:139:663-7. (2+).

17. Gottehrer A, Taryle DA, Reed CE, et al. Pleural fluid analysis in malignant mesothelioma. Prognostic implications. Chest 1991;100:1003-6. (3).

18. Burrows CM, Mathews WC, Colt HG. Predicting survival in patients with recurrent symptomatic malignant pleural effusions: an assessment of the prognostic values of physiologic, morphologic, and quality of life measures of extent of disease. Chest 2000:117:73-8. (2+)

19. Judson M, Sahn S. Pulmonary physiologic abnormalities caused by pleural disease Semin Respir Crit Care Med 1995:16:346-53. (4).

20. Maher GG, Berger HW. Massive pleural effusion: malignant and nonmalignant causes in 46 patients. Am Rev Respir Dis 1972;105:458-60. (3)

21. Parulekar W, Di Primio G, Matzinger F, et al. Use of small-bore vs large-bore chest tubes for treatment of malignant pleural effusions. Chest 2001;120:19-25. $(2+)$.

22. Clementsen $\mathbf{P}$, Evald $T$, Grode $G$, et al. Treatment of malignant pleural effusion: pleurodesis using a small percutaneous catheter. A prospective randomized study. Respir Med 1998;92:593-6. (1+).

23. Caglayan B, Torun E, Turan D, et al. Efficacy of iodopovidone pleurodesis and comparison of small-bore catheter versus large-bore chest tube. Ann Surg Oncol 2008:15:2594-9. (1+).

24. Seaton KG, Patz EF Jr, Goodman PC. Palliative treatment of malignant pleural effusions: value of small-bore catheter thoracostomy and doxycycline sclerotherapy. AJR 1995:164:589-91. (2+)

25. Morrison MC, Mueller PR, Lee MJ, et al. Sclerotherapy of malignant pleura effusion through sonographically placed small-bore catheters. AJR 1992;158:41-3. $(2+)$

26. Parker LA, Charnock GC, Delany DJ. Small bore catheter drainage and sclerotherapy for malignant pleural effusions. Cancer 1989;64:1218-21. (3).

27. Feller-Kopman D, Walkey A, Berkowitz D, et al. The relationship of pleural pressure to symptom development during therapeutic thoracentesis. Chest 2006:129:1556-60. (2-)

28. Sorensen PG, Svendsen TL, Enk B. Treatment of malignant pleural effusion with drainage, with and without instillation of talc. Eur J Respir Dis 1984;65:131-5. $(1-)$.

29. Zaloznik AJ, Oswald SG, Langin M. Intrapleural tetracycline in malignant pleural effusions. A randomized study. Cancer 1983;51:752-5. (1-).

30. Leverenz A, Heckmayr M, Tischer-Neuhauss $\mathrm{R}$, et al. Intrapleural palliative treatment of malignant pleural effusions with talcum versus placebo (pleural tube alone) [abstract]. Lung Cancer 2000;29A274. (1-).

31. Groth G, Gatzemeier U, Haussingen $\mathrm{K}$, et al. Intrapleural palliative treatment of malignant pleural effusions with mitoxantrone versus placebo (pleural tube alone) Ann Oncol 1991;2:213-15. (1+).

32. O'Neill W, Spurr C, Moss $\mathrm{H}$, et al. A prospective study of chest tube drainage and tetracycline sclerosis versus chest tube drainage alone in the treatment of malignant pleural effusions [abstract]. Proc Annu Meet Am Assoc Cancer Res 1980;21:349. (3).

33. Lambert CJ, Shah HH, Urshel HC Jr, et al. The treatment of malignant pleural effusions by closed trocar tube drainage. Ann Thorac Surg 1967;3:1-5. (2-)

34. Anderson CB, Philpott GW, Ferguson TB. The treatment of malignant pleural effusions. Cancer 1974:33:916-22. (3).

35. Izbicki R, Weyhing BT 3rd, Baker L, et al. Pleural effusion in cancer patients. A prospective randomized study of pleural drainage with the addition of radioactive phosphorous to the pleural space vs. pleural drainage alone. Cancer 1975;36:1511-18. (1-)

36. Boland GW, Gazelle GS, Girard MJ, et al. Asymptomatic hydropneumothorax after therapeutic thoracentesis for malignant pleural effusions. AJR 1998;170:943-6. $(2-)$.

37. Antony VB. Pathogenesis of malignant pleural effusions and talc pleurodesis Pneumologie 1999:53:493-8. (2+)

38. Antony VB, Rothfuss KJ, Godbey SW, et al. Mechanism of tetracyclinehydrochloride-induced pleurodesis. Tetracycline-hydrochloride-stimulated mesothelial cells produce a growth-factor-like activity for fibroblasts. Am Rev Respir Dis 1992;146:1009-13. (2-).

39. Antony VB, Nasreen N, Mohammed KA, et al. Talc pleurodesis: basic fibroblast growth factor mediates pleural fibrosis. Chest 2004;126:1522-8. (2-)

40. Rodriguez-Panadero F, Segado A, Martin Juan J, et al. Failure of talc pleurodesis is associated with increased pleural fibrinolysis. Am J Respir Crit Care Med 1995;151(3 Pt 1):785-90. (2+).

41. Xie C, Teixeira LR, McGovern JP, et al. Systemic corticosteroids decrease the effectiveness of talc pleurodesis. Am J Respir Crit Care Med 1998; 157(5 Pt 1):1441-4. $(2+)$

42. Haddad FJ, Younes RN, Gross JL, et al. Pleurodesis in patients with malignant pleural effusions: talc slurry or bleomycin? Results of a prospective randomized trial. World J Surg 2004;28:749-54. (1-). 
43. Hunt I, Teh $\mathrm{E}$, Southon $\mathrm{R}$, et al. Using non-steroidal anti-inflammatory drugs (NSAIDs) following pleurodesis. Interact Cardiovasc Thorac Surg 2007;6:102-4. (4)

44. Hausheer FH, Yarbro JW. Diagnosis and treatment of malignant pleural effusion. Semin Oncol 1985;12:54-75. (2-).

45. Owen S, Gould D. Underwater seal chest drains: the patient's experience. J Clin Nurs 1997:6:215-25. (2-)

46. Goff BA, Mueller PR, Muntz HG, et al. Small chest-tube drainage followed by bleomycin sclerosis for malignant pleural effusions. Obstet Gynecol 1993;81:993-6. (3)

47. Chen YM, Shih JF, Yang KY, et al. Usefulness of pig-tail catheter for palliative drainage of malignant pleural effusions in cancer patients. Support Care Cancer 2000;8:423-6. (2-)

48. Patz EF Jr, McAdams HP, Erasmus JJ, et al. Sclerotherapy for malignant pleural effusions: a prospective randomized trial of bleomycin vs doxycycline with smallbore catheter drainage. Chest 1998;113:1305-11. (1-).

49. Patz EF Jr, McAdams HP, Goodman PC, et al. Ambulatory sclerotherapy for malignant pleural effusions. Radiology 1996;199:133-5. (2-)

50. Tarver RD, Broderick LS, Conces DJ Jr. Reexpansion pulmonary edema. J Thorac Imaging 1996;11:198-209. (4)

51. Mahfood S, Hix WR, Aaron BL, et al. Reexpansion pulmonary edema. Ann Thorac Surg 1988:45:340-5. (3).

52. Nakamura H, Ishizaka A, Sawafuji M, et al. Elevated levels of interleukin-8 and leukotriene B4 in pulmonary edema fluid of a patient with reexpansion pulmonary edema. Am J Respir Crit Care Med 1994;149(4 Pt 1):1037-40. (3).

53. Trachiotis GD, Vricella LA, Aaron BL, et al. As originally published in 1988 Reexpansion pulmonary edema. Updated in 1997. Ann Thorac Surg 1997;63:1206-7. (4)

54. Adler RH, Sayek I. Treatment of malignant pleural effusion: a method using tube thoracostomy and talc. Ann Thorac Surg 1976;22:8-15. (3).

55. Villanueva AG, Gray AW Jr, Shahian DM, et al. Efficacy of short term versus long term tube thoracostomy drainage before tetracycline pleurodesis in the treatment of malignant pleural effusions. Thorax 1994;49:23-5. (1+).

56. Kennedy L, Rusch WW, Strange $\mathrm{C}$, et al. Pleurodesis using talc slurry. Chest 1994:106:342-6. (2-)

57. Robinson LA, Fleming WH, Galbraith TA. Intrapleural doxycycline control of malignant pleural effusions. Ann Thorac Surg 1993;55:1115-22. (2-).

58. Goodman A, Davies CWH. Efficacy of short-term versus long-term chest tube drainage following talc slurry pleurodesis in patients with malignant pleural effusions: a randomised trial. Lung Cancer 2006;54:51-5. (1-).

59. Pulsiripunya C, Youngchaiyud P, Pushpakom R, et al. The efficacy of doxycycline as a pleural sclerosing agent in malignant pleural effusion: a prospective study. Respirology 1996;1:69-72. (2-).

60. Wooten SA, Barbarash RA, Strange C et al. Systemic absorption of tetracycline and lidocaine following intrapleural instillation. Chest 1988;94:960-3. (2-).

61. Sherman S, Grady KJ, Seidman JC. Clinical experience with tetracycline pleurodesis of malignant pleural effusions. South Med J 1987;80:716-19. (2-).

62. Whitwam J, C W. Sedation and sedoanalgesia. In: Whitwam J, editor. Day-case anaesthesia and sedation. London: Blackwell Scientific Publications; 1994:262-74. (4).

63. Shaw P, Agarwal R. Pleurodesis for malignant pleural effusions. Cochrane Database Syst Rev 2004;(1):002916. (1++)

64. Tan C, Sedrakyan A, Browne J, et al. The evidence on the effectiveness of management for malignant pleural effusion: a systematic review. Eur J Cardiothorac Surg 2006;29:829-38. (1+).

65. Heffner JE, Unruh LC. Tetracycline pleurodesis. Adios, farewell, adieu. Chest 1992; 101:5-7. (4)

66. Bethune N. Pleural poudrage: new technique for deliberate production of pleural adhesions as preliminary to lobectomy. $J$ Thorac Cardiovasc Surg 1935; 4:251-61. (3)

67. Webb WR, Ozmen V, Moulder PV, et al. lodized talc pleurodesis for the treatment of pleural effusions. J Thorac Cardiovasc Surg 1992;103:881-6. (2-).

68. Yim AP, Chan AT, Lee TW, et al. Thoracoscopic talc insufflation versus talc slurry for symptomatic malignant pleural effusion. Ann Thorac Surg 1996;62:1655-8. (1-)

69. Marom EM, Patz EF Jr, Erasmus JJ, et al. Malignant pleural effusions: treatment with small-bore-catheter thoracostomy and talc pleurodesis. Radiology 1999;210:277-81. (2+).

70. Thompson RL, Yau JC, Donnelly RF, et al. Pleurodesis with iodized talc for malignant effusions using pigtail catheters. Ann Pharmacother 1998;32:739-42. (3).

71. Lynch TJ Jr. Optimal therapy of malignant pleural effusions: Report of a randomized trial of bleomycin, tetracycline, and talc and a meta-analysis. Int $J$ Oncol 1996;8:183-90. (1-)

72. Zimmer PW, Hill M, Casey K, et al. Prospective randomized trial of talc slurry vs bleomycin in pleurodesis for symptomatic malignant pleural effusions. Chest 1997; 112:430-4. (1+)

73. Manes N, Rodriguez-Panadero F, Bravo J, et al. Talc pleurodesis. Prospective and randomized study clinical follow up [abstract]. Chest 2000;118:131S. (1-).

74. Dresler CM, Olak J, Herndon JE 2nd, et al. Phase 3 intergroup study of talc poudrage vs talc slurry sclerosis for malignant pleural effusion. Chest 2005; 127:909-15. (1-).

75. Stefani A, Natali P, Casali C, et al. Talc poudrage versus talc slurry in the treatment of malignant pleural effusion. A prospective comparative study. Eur J Cardiothorac Surg 2006;30:827-32. (2-).
76. Diacon AH, Wyser C, Bolliger CT, et al. Prospective randomized comparison of thoracoscopic talc poudrage under local anesthesia versus bleomycin instillation for pleurodesis in malignant pleural effusions. Am J Respir Crit Care Med 2000;162(4 Pt 1):1445-9. (1+).

77. Kuzdzal J, Sladek K, Wasowski D, et al. Talc powder vs doxycycline in the contro of malignant pleural effusion: a prospective, randomized trial. Med Sci Monitor 2003;9:PI54-9. (1-)

78. Fentiman IS, Rubens RD, Hayward JL. A comparison of intracavitary talc and tetracycline for the control of pleural effusions secondary to breast cancer. Eur $J$ Cancer Clin Oncol 1986;22:1079-81. (1-)

79. Brant A, Eaton T. Serious complications with talc slurry pleurodesis. Respirology 2001:6:181-5. (2-)

80. Rinaldo JE, Owens GR, Rogers RM. Adult respiratory distress syndrome following intrapleural instillation of talc. J Thorac Cardiovasc Surg 1983;85:523-6. (3).

81. Bouchama A, Chastre J, Gaudichet $A$, et al. Acute pneumonitis with bilateral pleural effusion after talc pleurodesis. Chest 1984;86:795-7. (3).

82. Rehse DH, Aye RW, Florence MG. Respiratory failure following talc pleurodesis. Am J Surg 1999;177:437-40. (2-).

83. Campos JRM, Werebe EC, Vargas FS, et al. Respiratory failure due to insufflated talc. Lancet 1997:349:251-2. (3).

84. Nandi P. Recurrent spontaneous pneumothorax; an effective method of talc poudrage. Chest 1980;71:493-5. (4).

85. Ferrer J, Villarino MA, Tura JM, et al. Talc preparations used for pleurodesis vary markedly from one preparation to another. Chest 2001;119:1901-5. $(\mathbf{2 + + 1}$

86. Kuzniar T, Mutlu GM. Post-talc pleurodesis acute lung injury: case report and review of literature. Adv Clin Exp Med 2004:13:367-70. (3)

87. Bondoc AY, Bach PB, Sklarin NT, et al. Arterial desaturation syndrome following pleurodesis with talc slurry: incidence, clinical features, and outcome. Cancer Invest 2003;21:848-54. (2-)

88. Maskell NA, Lee YC, Gleeson FV, et al. Randomized trials describing lung inflammation after pleurodesis with talc of varying particle size. Am J Respir Crit Care Med 2004;170:377-82. (1+)

89. Janssen JP, Collier G, Astoul P, et al. Safety of pleurodesis with talc poudrage in malignant pleural effusion: a prospective cohort study. Lancet 2007:369:1535-9. $(2++)$

90. Werebe EC, Pazetti R, Milanez de Campos JR, et al. Systemic distribution of talc after intrapleural administration in rats. Chest 1999;115:190-3. (2+).

91. Fraticelli A, Robaglia-Schlupp A, Riera $\mathrm{H}$, et al. Distribution of calibrated talc after intrapleural administration: an experimental study in rats. Chest 2002;122:1737-41. (2+).

92. Ferrer J, Montes JF, Villarino MA, et al. Influence of particle size on extrapleural talc dissemination after talc slurry pleurodesis. Chest 2002;122:1018-27. $(2+)$.

93. Alberts DS, Chen HS, Mayersohn M, et al. Bleomycin pharmacokinetics in man. 2 Intracavitary administration. Cancer Chemother Pharmacol 1979:2:127-32. (3)

94. Bitran JD, Brown C, Desser RK, et al. Intracavitary bleomycin for the control of malignant effusions. J Surg Oncol 1981;16:273-7. (3)

95. Emad A, Rezaian GR. Treatment of malignant pleural effusions with a combination of bleomycin and tetracycline. A comparison of bleomycin or tetracycline alone versus a combination of bleomycin and tetracycline. Cancer 1996;78:2498-501. $(1-)$.

96. Hamed H, Fentiman IS, Chaudary MA, et al. Comparison of intracavitary bleomycin and talc for control of pleural effusions secondary to carcinoma of the breast. $\mathrm{Br} J$ Surg 1989;76:1266-7. (1+)

97. Hartman DL, Gaither JM, Kesler KA, et al. Comparison of insufflated talc under thoracoscopic guidance with standard tetracycline and bleomycin pleurodesis for control of malignant pleural effusions. J Thorac Cardiovasc Surg 1993;105:743-8. $(2-)$.

98. Kessinger A, Wigton RS. Intracavitary bleomycin and tetracycline in the management of malignant pleural effusions: a randomized study. J Surg Oncol 1987:36:81-3. (1-)

99. Martinez-Moragon E, Aparicio J, Rogado MC, et al. Pleurodesis in malignant pleural effusions: a randomized study of tetracycline versus bleomycin. Eur Respir $J$ 1997:10:2380-3. $(\mathbf{1}+)$

100. Noppen M, Degreve J, Mignolet $M$, et al. A prospective, randomised study comparing the efficacy of talc slurry and bleomycin in the treatment of malignant pleural effusions. Acta Clin Belg 1997:52:258-62. (1+)

101. Ong KC, Indumathi $V$, Raghuram J, et al. A comparative study of pleurodesis using talc slurry and bleomycin in the management of malignant pleural effusions. Respirology 2000;5:99-103. (1-).

102. Ruckdeschel JC, Moores D, Lee JY, et al. Intrapleural therapy for malignant pleural effusions. a randomized comparison of bleomycin and tetracycline [erratum appears in Chest 1993;103:1640]. Chest 1991;100:1528-35. $(\mathbf{1 + + )}$.

103. Hsu WH, Chiang CD, Chen CY, et al. Ultrasound-guided small-bore Elecath tube insertion for the rapid sclerotherapy of malignant pleural effusion. Jpn J Clin Oncol 1998;28:187-91. (3).

104. Kilic D, Akay H, Kavukcu S, et al. Management of recurrent malignant pleural effusion with chemical pleurodesis. Surg Today 2005;35:634-8. (3).

105. Lorch DG, Gordon L, Wooten S, et al. Effect of patient positioning on distribution of tetracycline in the pleural space during pleurodesis. Chest 1988;93:527-9. (3).

106. Dryzer SR, Allen ML, Strange C, et al. A comparison of rotation and nonrotation in tetracycline pleurodesis. Chest 1993;104:1763-6. (1-) 
107. Mager HJ, Maesen B, Verzijlbergen F, et al. Distribution of talc suspension during treatment of malignant pleural effusion with talc pleurodesis. Lung Cancer 2002;36:77-81. (1+).

108. Sahn SA. Pleural diseases related to metastatic malignancies. Eur Respir J 1997;10:1907-13. (4).

109. Lynch TJ Jr. Management of malignant pleural effusions. Chest 1993; 103(4 Suppl):385-9S. (4)

110. Jones FL Jr. Subcutaneous implantation of cancer: a rare complication of pleural biopsy. Chest 1970:57:189-90. (3).

111. Berger RL, Dargan EL, Huang BL. Dissemination of cancer cells by needle biopsy of the lung. J Thorac Cardiovasc Surg 1972;63:430-2. (3).

112. Kumar UN, Varkey B. Case report: subcutaneous metastasis. Rare complication of drainage of malignant pleural fluid. Postgrad Med 1976;60:253-5. (3).

113. Chen TP, Liu HP, Lu HI, et al. Incidence of incisional recurrence after thoracoscopy. Surg Endosc 2004;18:540-2. (2-).

114. Boutin C, Rey F, Viallat JR. Prevention of malignant seeding after invasive diagnostic procedures in patients with pleural mesothelioma. A randomized trial of local radiotherapy. Chest 1995;108:754-8. (1+).

115. O'Rourke N, Garcia JC, Paul J, et al. A randomised controlled trial of intervention site radiotherapy in malignant pleural mesothelioma. Radiother Oncol 2007; 84:18-22. $(\mathbf{1}+)$

116. Bydder S, Phillips M, Joseph DJ, et al. A randomised trial of single-dose radiotherapy to prevent procedure tract metastasis by malignant mesothelioma. $\mathrm{Br}$ $J$ Cancer 2004;91:9-10. (1+)

117. Low EM, Khoury GG, Matthews AW, et al. Prevention of tumour seeding following thoracoscopy in mesothelioma by prophylactic radiotherapy. Clin Oncol 1995; 7:317-18. (3)

118. Agarwal PP, Seely JM, Matzinger FR, et al. Pleural mesothelioma: sensitivity and incidence of needle track seeding after image-guided biopsy versus surgical biopsy. Radiology 2006;241:589-94. (2-).

119. West SD, Foord T, Davies RJ. Needle-track metastases and prophylactic radiotherapy for mesothelioma. Respir Med 2006;100:1037-40. (2-).

120. Davies CW, Traill ZC, Gleeson FV, et al. Intrapleural streptokinase in the management of malignant multiloculated pleural effusions. Chest 1999;115:729-33. (3).

121. Gilkeson RC, Silverman P, Haaga JR. Using urokinase to treat malignant pleural effusions. AJR 1999;173:781-3. (3).

122. Hsu L-H, Soong TC, Feng A-C, et al. Intrapleural urokinase for the treatment of loculated malignant pleural effusions and trapped lungs in medically inoperable cancer patients. J Thorac Oncol 2006;1:460-7. (2-).

123. Tillett WS, Sherry $\mathbf{S}$. The effect in patients of streptococcal fibrinolysin and streptococcal desoxyribonuclease on fibrinous, purulent, and sanguinous pleural exudations. J Clin Invest 1949;28:173-90. (3)

124. Godley PJ, Bell RC. Major hemorrhage following administration of intrapleural streptokinase. Chest 1984;86:486-7. (3).

125. Loddenkemper R. Thoracoscopy: state of the art. Eur Respir J 1998;11:213-21. (4)

126. Harris RJ, Kavuru MS, Rice TW, et al. The diagnostic and therapeutic utility of thoracoscopy. A review. Chest 1995;108:828-41. (4).

127. Menzies R, Charbonneau M. Thoracoscopy for the diagnosis of pleural disease. Ann Intern Med 1991:114:271-6. (3)

128. Danby CA, Adebonojo SA, Moritz DM. Video-assisted talc pleurodesis for malignant pleural effusions utilizing local anesthesia and I.V. sedation. Chest 1998:113:739-42. (3)

129. Arapis K, Caliandro R, Stern JB, et al. Thoracoscopic palliative treatment of malignant pleural effusions: results in 273 patients. Surg Endosc 2006;20:919-23. $(2+)$.
130. Canto A, Blasco E, Casillas M, et al. Thoracoscopy in the diagnosis of pleural effusion. Thorax 1977;32:550-4. (3)

131. Ferrer J, Roldan J, Teixidor J, et al. Predictors of pleural malignancy in patients with pleural effusion undergoing thoracoscopy. Chest 2005;127:1017-22. (2+).

132. Aelony Y, King RR, Boutin C. Thoracoscopic talc poudrage in malignant pleural effusions: effective pleurodesis despite low pleural pH. Chest 1998;113:1007-12. $(2-)$

133. Debeljak A, Kecelj P, Triller N, et al. Talc pleurodesis: comparison of talc slurry instillation with thoracoscopic talc insufflation for malignant pleural effusions. J BUON 2006;11:463-7. (2-).

134. Foroulis CN, Kotoulas C, Konstantinou M, et al. The management of malignant pleural effusions: talc pleurodesis versus bleomycin pleurodesis. J BUON 2001;6:397-400. (3).

135. Harley HR. Malignant pleural effusions and their treatment by intercostal talc pleurodesis. Br J Dis Chest 1979:73:173-7. (3).

136. Jones GR. Treatment of recurrent malignant pleural effusion by iodized talc pleurodesis. Thorax 1969:24:69-73. (3).

137. Viallat JR, Rey F, Astoul P, et al. Thoracoscopic talc poudrage pleurodesis for malignant effusions. A review of 360 cases. Chest 1996;110:1387-93. (2-).

138. Weissberg D, Ben-Zeev I. Talc pleurodesis. Experience with 360 patients. J Thorac Cardiovasc Surg 1993;106:689-95. (2-).

139. Gasparri R, Leo F, Veronesi G, et al. Video-assisted management of malignant pleural effusion in breast carcinoma. Cancer 2006:106:271-6. (2-).

140. Qureshi RA, Collinson SL, Powell RJ, et al. Management of malignant pleural effusion associated with trapped lung syndrome. Asian Cardiovasc Thorac Ann 2008:16:120-3. (2-)

141. Colt HG. Therapeutic thoracoscopy. Clin Chest Med 1998;19:383-94. (4)

142. Cardillo G, Facciolo F, Carbone L, et al. Long-term follow-up of video-assisted talc pleurodesis in malignant recurrent pleural effusions. Eur $\mathrm{J}$ Cardiothorac Surg 2002;21:302-6. $(2+)$

143. de Campos JR, Vargas FS, de Campos Werebe $\mathrm{E}$, et al. Thoracoscopy talc poudrage: a 15-year experience. Chest 2001;119:801-6. (2+).

144. Pien GW, Gant MJ, Washam CL, etal. Use of an implantable pleural catheter for trapped lung syndrome in patients with malignant pleural effusion. Chest 2001;119:1641-6. (3)

145. Putnam JB Jr, Walsh GL, Swisher SG, et al. Outpatient management of malignant pleural effusion by a chronic indwelling pleural catheter. Ann Thorac Surg 2000;69:369-75. (2+).

146. Warren W, Faber L. Clinical experience with Pleurx catheters for malignant pleura effusions. Chest 2000;118(Suppl):130S. (3).

147. Warren WH, Kalimi R, Khodadadian LM, et al. Management of malignant pleura effusions using the Pleur(x) catheter. Ann Thorac Surg 2008;85:1049-55. (2-).

148. Tremblay A, Michaud G. Single-center experience with 250 tunnelled pleural catheter insertions for malignant pleural effusion. Chest 2006;129:362-8. (2-).

149. Bertolaccini L, Zamprogna C, Barberis L, et al. Malignant pleural effusions: review of treatment and our experience. Rev Recent Clinical Trials 2007:2:21-5. (2-)

150. Janes SM, Rahman NM, Davies RJ0, et al. Catheter-tract metastases associated with chronic indwelling pleural catheters. Chest 2007;131:1232-4. (3).

151. Martini N, Bains MS, Beattie EJ Jr. Indications for pleurectomy in malignant effusion. Cancer 1975:35:734-8. (3).

152. Fry WA, Khandekar JD. Parietal pleurectomy for malignant pleural effusion. Ann Surg Oncol 1995:2:160-4. (2-).

153. Bernard A, de Dompsure RB, Hagry 0, et al. Early and late mortality after pleurodesis for malignant pleural effusion. Ann Thorac Surg 2002;74:213-17. (2-).

154. Waller DA, Morritt GN, Forty J. Video-assisted thoracoscopic pleurectomy in the management of malignant pleural effusion. Chest 1995:107:1454-6. (3) 